\title{
BANK LIQUIDITY RISK: SIGNIFICANCE OF FINANCIAL DISCLOSURE AND GOVERNANCE PRACTICE
}

\author{
Niluthpaul \\ Sarker $^{1+}$ \\ (i) Probir Kumar \\ Bhowmik $^{2}$
}

\author{
'Associate Professor, Department of Accounting \&' Information \\ Systems, Jagannath University, Dhaka, Bangladesh. \\ Email:niluthpaul@yahoo.com Tel: +8801746146878 \\ 'Assistant Professor, Department of Accounting \& Information \\ Systems, University of Barishal, Barishal, Bangladesh. \\ Email:probir9012@gmail.com Tel: +8801913518309
}

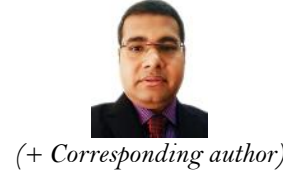

ABSTRACT

Article History

Received: 10 May 2021 Revised: 14 July 2021 Accepted: 16 August 2021 Published: 8 September 2021

\section{Keywords \\ Liquidity risk \\ Corporate governance \\ Financial disclosure \\ Commercial banks \\ Two-stage least squares \\ Bangladesh.}

\section{JEL Classification:} C12; C33.

\begin{abstract}
The objective of the study is to show the remedial effect of bank liquidity risk in the marketplace by disseminating financial information and practicing corporate governance mechanisms. The link between financial disclosure, corporate governance, and banks' liquidity risk management in Bangladesh is examined in this paper. The study used panel data on 32 commercial banks from the 2008 to 2018 with 346 observations collected from published annual reports. Based on the preliminary diagnosis, the study chose the two-stage least squares (2SLS) regression method to minimize the errors arising from heteroskedasticity, autocorrelation, and endogeneity issues. The study found that adequate financial disclosure and corporate governance practices minimize bank liquidity risk to maintain a stable image in the minds of investors and withstand immense regulatory pressure. To allow banks to detect issues early, they must implement changes quickly and be more robust to crises, thus risk management efficacy and excellent corporate governance implementation are required. Moreover, banks are mainly concerned about liquidity risk as it directly affects the market's performance and stability. Liquidity crises can be eradicated by proper monitoring and providing information pertaining to risks to prudent investors in a reliable and transparent corporate culture.
\end{abstract}

Contribution/Originality: The use of a 2SLS regression model to explain the link between financial disclosure, corporate governance, and bank liquidity risk from research on Bangladesh adds to the current literature. This research paves the way for academics and practitioners to investigate bank risk in Bangladesh so that they can ensure transparency and a favorable market image on the global platform.

\section{INTRODUCTION}

The diversified functions of banks expose them to a liquidity crisis - the risk that a bank will not satisfy its obligations (Jenkinson, 2008) - if depositors call in their funds at an awkward moment, triggering asset-based sales (Diamond \& Rajan, 2001) and adversely impacting bank profitability (Chaplin, Emblow, \& Michael, 2000; Diamond \& Rajan, 2001).

Bank managers have not paid the requisite attention over the last few years to this critical aspect of liquidity risk. However, following numerous economic and banking crises across the globe, it has recently attracted considerable interest from academics, regulators, and financial institutions. There was an inevitable perception that the existing risk management practices did not adequately cover liquidity risk (Crowe, 2009). The study of 
conducted by (Ali, 2004) revealed that liquidity risk is a threat for the existence of banks in the competitive market and, hence is called the assassin of the banks. This argument is supported by the recent collapse of several banks, and now banks and regulators have a profound view into banks' liquidity vulnerabilities.

Liquidity vulnerability not only influences the efficiency of a bank but also its credibility (Jenkinson, 2008). If funds are not issued in a timely manner, a bank may lose the confidence of its depositors and the credibility of the bank may be at stake. In addition to this, the regulator can impose penalties based on poor liquidity conditions. Therefore, establishing a sound liquidity agreement is crucial for a bank. For modern banks, liquidity risk has been a serious threat; banks face a range of other threats, such as default risk, operating risk, and interest rate risk, which may result in liquidity risk (Brunnermeier \& Yogo, 2009).

Traditional corporate governance structures have proved incapable of protecting large financial institutions from significant financial problems and controversies in developing economies, as recently shown by the Lehman brothers' bankruptcy in September 2008 or the Libor rate-fixing scandal discovered in June 2012 involving numerous US and European banks (Barclays, Deutsche Bank, Royal Bank of Scotland, and UBS).

The Basel I and II Accords, credit risk, market risk and operating risk regulatory requirements have been extensively discussed, but liquidity risk has not despite it being one of the biggest threats to banks and other financial institutions in recent years. Landskroner \& Paroush (2008) suggested that numerous banking risks (credit risk, business risk, and operating risk) have been explored thoroughly in academic and regulatory terms. The Basel Committee on Banking Supervision (BCBS) suggested that liquidity risk emerges from a bank's failure to handle liability declines or inability to fund asset increases. An illiquid bank means that, either by raising liabilities or by promptly transferring assets at a fair rate, it cannot receive adequate funds. Bank profitability is now declining because of illiquidity. Decker (2000) split liquidity risk into finance and business liquidity risks. Matz \& Neu (2006) also demonstrated that banks should carry out a liquidity analysis of their balance sheets, cash capital status, and their approach to maturity mismatch to determine liquidity danger. This research, however, uses Saunders \& Corrnet (2007) and DeYoung \& Jang (2016) to evaluate the funding gap to determine the risk of bank liquidity, where the financial gap is the disparity between loans and core deposits. This measure is readily accessible across countries and can thus provide a means to avoid any such risks.

This research gathered data on the commercial banks of Bangladesh from 2008 to 2018. Estimates of the factors of liquidity vulnerability are derived from the fixed effects regression model. This analysis explores alternate liquidity risk indicators to examine the determinants of liquidity risk. As an endogenous determinant of bank disclosure, governance mechanisms and liquidity risks are described. This research also analyzes and examines the variations in the causes of liquidity risk across different financial structures.

\section{LITERATURE REVIEW}

\subsection{Bank Liquidity Risk}

According to IFRS 7, liquidity risk is a significant form of bank risk. In most situations, liquidity tests are from total assets to existing liabilities (Gombola, Haskins, Ketz, \& Williams, 1987). This is one of the most popular liquidity metrics used in research. The liquidity ratio or thumb rule standard is $2: 1$, meaning banks should hold liquid assets two times more of liquid or current liabilities. What if banks don't uphold the standard? If the bank holds a ratio below the norm (liquidity ratio $<2: 1$ ), this implies that they are in a precarious situation with a higher chance of liquidation. The explanation is that banks cannot pay timely short-term duties. On the other hand, if the ratio approaches the norm (liquidity $>2: 1$ ), the bank will also consider inefficient banks. The explanation is that the bank has perfect capital that can be used to raise money; it also entails the opportunity cost of money. Studies performed by Beaver (1966) explained that companies with more liquid reserves are less likely to collapse. In the distress appraisal of the company, the Altman (1968) model and the Ohlson (1980) model are very influential and often considered as bankruptcy 
models. Another study by Flagg, Giroux, \& Wiggins Jr (1991) indicated that some financial metrics such as profitability, debt, and liquidity are core components of the bankruptcy model. In reality, a liquidity crisis puts banks in a risky situation where there is a risk of liquidation, and their reputation often falls in the market. As a consequence, they cannot repay at a higher interest rate, which eventually interrupts their regular service (Theodossiou, Kahya, Saidi, \& Philippatos, 1996). In the deteriorating process, the company entity encountered financial pressure forcing the liquidation of divisions (Miller \& Friesen, 1984) or selling valuable assets (Theodossiou et al., 1996). At the time, they sought to raise the company's liquidity by any means possible to decrease the risk of financial distress. Hendel (1996) suggested that "liquidity consideration exacerbates price cyclicality and smooth sales", a paradigm which holds that companies adapt their mix of assets between liquid and illiquid assets during the crisis cycle where the firm's current asset is not optimum.

Elloumi \& Gueyie (2001) found that companies have lower liquidity and higher debt during the distress phase. Campbell, Hilscher, \& Szilagyi (2008), however, revealed the firm's loss determinant where low liquidity is an important ingredient. In reality, distressed companies are defined by factors that include lower market value of shares, higher debt, and liquidity shortfall or cash flow problems (Chan \& Chen, 1991). It is believed, however, that variance in leverage and liquidity will solve the problem and dramatically affect efficiency and productivity (Shaik, 2015). According to Daily \& Dalton (1994), liquidity decline raises the risks of financial distress.

Bank lending depends on the loan ratio and advances to overall assets. Previous research performed by Brucker (1970) found that bank output improves as loans and advances rise. Indeed, higher loan grants demonstrate the desire and capacity of banks to turn unused reserves into useful capital, which is how banks play a part in capital creation (Moulton, 1981). Moreover, bank efficiency often relies on the risk of defaults producing more bad loans.

This shows that the correct balance of debt improves the financial base and raises a company's worth by tax shielding (MM Hypothesis, Proposition II). However, banks' risky higher debt strategies damage capital structure and raises risk. The figure below shows financial distress and valuation cost:

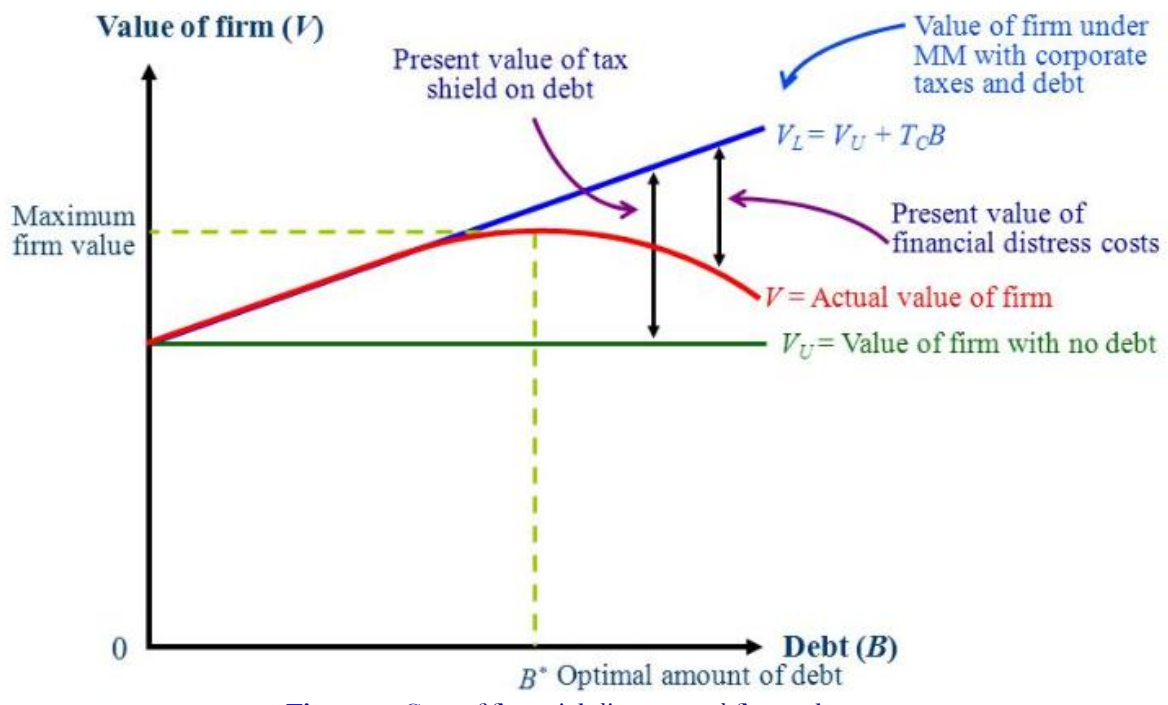

Figure 1. Cost of financial distress and firm value.

The worth of a leveraged company is determined by the value of the un-levered firm plus the tax shield, as shown in Figure 1, i.e., VL $=\mathrm{VU}+\mathrm{TCB}$. Thus, $\mathrm{B}^{*}$ is the optimal point at which banks may maximize their worth while balancing the cost of financial distress with the tax benefit. The rationale behind this is that increasing debt can cause financial distress, lowering the firm's value.

Leverage is determined by the ratio of net debt to total assets. This reflects the portion of debt protected by assets; a higher percentage indicates the weakness of a company. In their bankruptcy analysis, Flagg et al. (1991) 
proposed three forms of risk measure - profitability, liquidity, and leverage. Banking theories showed a negative correlation between liquidity and profitability, and the explanation is that if banks hold more liquid assets, they will lend less as loans and advances that will diminish their benefits. It was also observed that rising leverage and lax governance structures are responsible for low profitability (Daily \& Dalton, 1994), and eventually lead to bankruptcy.

The liquidity risk problems are addressed by the Basel II agreement proposed by the Basel Committee on Banking Supervision (BCBS) in a regulatory structure on bank capital, leverage, and liquidity. In fact, the BCBS seeks to control global conformity to its suggested standards, but they have no legal power that can force banks to obey their rules in BCBS member countries or non-member countries (Shin, 2009). Currently, the BCBS has issued three consecutive standard sets, Basel I, Basel II, and Basel III. The first two agreements disregard the liquidity risk. After the 2007-2008 financial crisis, the need for best liquidity management practice received considerable attention from policymakers. The results of the global financial crisis hastened the necessity to integrate liquidity issues into the Basel III deal. Under Basel III, two complementary ratios cover liquidity requirements, i.e., liquidity coverage ratio (LCR) and net stable funding ratio (NSFR). The LCR was made available from January 1, 2015, and the NSFR from January 1, 2018. The objective of the LCR is to strengthen a bank's ability to tackle short-term liquidity shocks. The LCR calculation formula is given below:

\section{$L C R=\frac{\text { Stock of high quality liquid assets }}{\text { Total NCO over the next } 30 \text { days }}$}

The formula for the NSFR is:

\section{$N S F R=\frac{\text { Available amount of stable funding }}{\text { Required amount of stable funding }}$}

According to the BCBS, the NSFR aims to promote long-term, stable funding for banks.

From empirical data, Cecchetti, Schoenholtz, \& Cecchetti (2011) established that liquidity risk resulted from the possibility of the depositors withdrawing their bank deposits. Diamond \& Dybvig (1983) and Bryant (1980) found that liquidity risk and credit risk are often related where deposits are from depositor and borrower defaults. However, Berger \& Bouwman (2009) reported that the liquidity problem was the main factor in the 2007 banking crisis. Vazquez \& Federico (2015) described the relationship between bank structure leverage and liquidity and its effect on financial stability during the crisis phase, and the less liquid banks with higher debt were found to have a greater risk of bankruptcy.

From the above discussion, the main factor of the financial crisis is liquidity risk. Therefore, the analysis is called the liquidity vulnerability of bank disclosures and governance framework.

\section{BLR 1 $=\frac{\text { Total Loan and Advances }}{\text { Total Deposits }}$}

\section{BLR 2 $=\frac{\text { Total Loan and Advances }}{\text { Total Assets }}$}

\subsection{Bank Disclosures}

Contemporary issues of bank risk management are often limited to financial statements and corporate governance structures. It has been observed that the default probability reduces by increasing transparency and implementing clear business disciplines promoting capital buffer selection. Another study conducted by Baumann \& Nier (2004) showed that bank disclosures decrease conflict of interest among stakeholders and also have an inverse 
impact on stock price volatility. The transparency index is based on four broad segments - properties, liabilities, memo lines, and income statements. The study showed that banks with higher disclosures operate with low risk than banks with lower disclosures to the public.

Research undertaken by Hirtle (2007) found a link between bank disclosures and their results where the bank holding companies' (BHC) risk profiles are provided depending on the amount of disclosure. The study developed a risk profile index based on BHC's publicly traded information, particularly information concerning banks' forwardlooking activities in their trading and decision-making platforms. It explores the correlation between the disclosure index and BHC's operational activities' risk-return trend. Bank output is proxied by market return, and the study revealed that banks with higher disclosure mitigate risk, particularly idiosyncratic risk, and lower disclosure compensated banks' returns. In reality, higher transparency commensurate two-fold targets, first, lowering the overall bank risk, and second, rising bank productivity that boosts profit.

Hossain (2008) researched India's banking industry by exploring the level of transparency in banks' annual reports. He found that many variables are important in detailing the degree of size, performance, board structure, and business discipline disclosures. He also found that age, market sophistication, and asset-in-place variables have a negligible impact on annual disclosure. The report also showed that banks comply with required reporting while overlooking optional disclosures.

It is common for banks to want to ignore voluntary disclosures when there is no administrative burden. However, from the viewpoint of stakeholders, banks should disclose all related information so that consumers can make well-informed decisions. Transparency level was favorably correlated with ownership structure and company performance (i.e., ROA and ROE). Often, ownership arrangement is divided into state ownership and international ownership. This study found that comprehensive voluntary transparency does not impact debt costs. Further research by Putu, Moeljadi, \& Djazuli (2014) empirically shows the impact of voluntary transparency on earnings management of banks listed on the Indonesian Stock Exchange. They found that mutual transparency reverses the effect on earnings control. In reality, more voluntary disclosures decreased banks' profits. Therefore, bank statements play a crucial role for those who make their decisions based on annual reports.

Again, Bischof \& Daske (2012) steered their Eurozone bank studies based on bank-specific disclosures. They found the stress test and sovereign debt crisis as their investigative premise. They found that required disclosures improve participants' capacities to provide accurate detail and higher transparency decreases bank opaqueness. It also finds unfavorable stress checks linked to the elimination of sovereign risk-taking. However, supervisory disclosure efficacy is gained by reducing financial market volatility that affects banks' lower risk-taking behavior. There are two types of disclosure style in annual reports, one required and the other optional (Putu et al., 2014). Mandatory reports are obligatory for banks to publish in their annual reports and have strict boundaries defined by regulatory authorities, while optional disclosures are published for the broader public benefit (Adina \& Ion, 2008). In fact, voluntary disclosures are supplementary details for the general public and reinforce the stakeholder theory in business agreements.

The disclosure index was prepared in the analysis in conjunction with the factors listed by Nier \& Baumann (2006), where 17 items were grouped into four headings (assets, liabilities, memo lines, and income statements) (see Figure 2), which display the impacts on bank risk for credit risk, market risk, and liquidity risk along with the overall bank risk. They assigned a value of " 1 " for disclosure and " $\mathrm{O}$ " for non-disclosure to each item. They gave a value of "O" for non-disclosure, "1" for full contrast, and "2" for detailed breakdown of each of the three items (S6, S7, and S13). They came to another conclusion based on these three items, with "1" indicating a complete breakdown of three and "o" indicating the opposite. The below is how the disclosures are calculated:

$$
\text { Bank Disclosures Index }(B D I)=\frac{1}{21} \sum_{i=1}^{17} S_{i}
$$




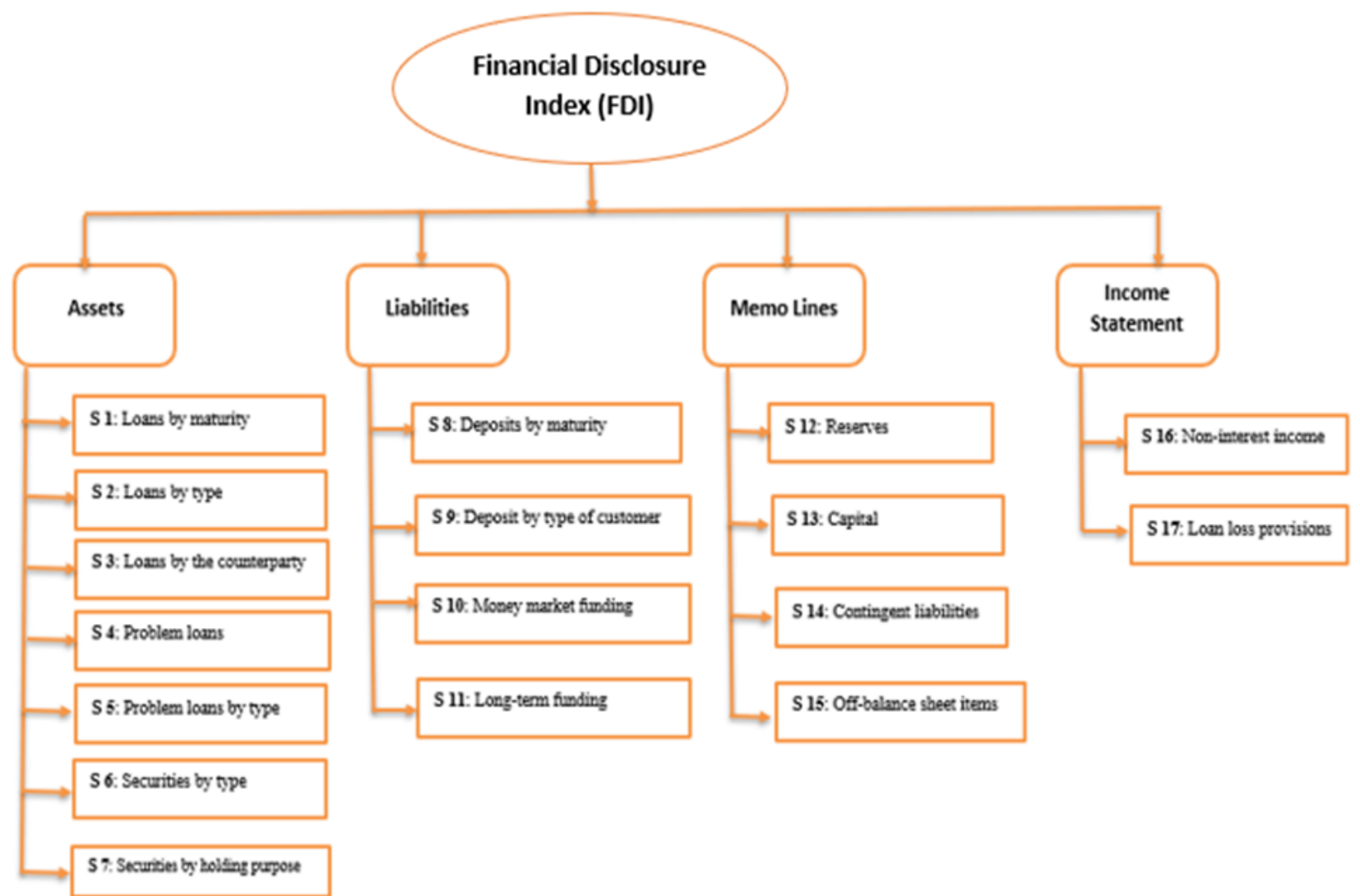

Figure 2. Financial disclosure index.

Source: Nier and Baumann (2006)

\subsection{Corporate Governance}

Banking companies can accomplish their targets by exercising good governance practice. Corporate governance is argued to shadow tight business disciplines where the internal and external management mechanisms achieve bank transparency (Flannery, 2001). It is also observed that banks' risk-taking activities are controlled by regulatory oversight, creating a stable consumer financial position.

Data from the analysis performed by Konishi \& Yasuda (2004) showed that risk-taking activities of commercial banks can be eliminated by executing capital adequacy provisions suggested by the Basel standards. The results favor the presence of former government officials as board members, which dramatically affects bank risk. Another study by Laeven \& Levine (2009) showed that shareholder structure within the corporate governance system impacts banks' risk-taking actions. Every bank's governance structure differs from other banks and lacks required legislation. In particular, the study emphasizes banks' ownership concentration, showing the control of the majority of the shareholders reflected in the risk-taking actions along with capital regulations and deposit insurance policies. They disclosed that each bank's practice of rules and regulations impacts its risk actions differently, only because of corporate governance structure practices.

Beltratti \& Stulz (2012) analyzed the shareholder-friendly board index to show the impact on business risk. They use default risk, equity risk, leverage risk, and portfolio risk defining different proxies as the Z-score, stock volatility, debt asset ratio, and asset-to-asset ratio consecutively. However, their results are somewhat inconsistent, as shareholder-friendly boards had a favorable effect on default risk, but the argument was not true for the other forms of risk.

Erkens, Hung, \& Matos (2012) published their research demonstrating the impact of autonomous managers on risk-taking behaviors. Using the three risk steps, i.e., default risk, equity risk, and debt risk, based on default frequency, market turnover and additional capital increase. They revealed that independent directors had no 
association with reducing credit risk and equity risk. The debt risk is minimized by including independent directors in the board structure, though they favor raising equity capital through financial turbulence.

Berger, Kick, \& Schaeck (2014) worked on corporate governance demographics from a bank risk perspective. They concentrated on managers' qualitative features of age, education, and gender. The analysis considered portfolio risk by concentration of asset density and loan portfolio. The results showed that younger executives had comparable optimistic portfolio risk relationships to female directors. Another study by Minton \& Williamson (2014) focused on the expertise of independent financial institution administrators. The research used the risk indicator as equity risk, debt risk, and fund risk dependent on stock volatility, risk-adjusted capital ratio, and fractions of real-estate collateral consecutively. The findings were above expectation as the makeup of board members with higher financial market experience favorably impacting bank risk.

Recently, the IMF (2014) has performed studies on board size and the makeup of independent directors. The study considered default risk, asset risk, and tail risk in the Z-score and included stock volatility and anticipated and marginal shortfall in their model. The investigation found that the board's higher number of independent directors was negatively correlated with bank risk, whilst the board's higher proportion of financial analysts positively affected bank risk.

The Securities and Exchange Commission (hereinafter referred to as the "Commission") considers it appropriate that the consent already given by the Commission, or to be given in the future to the issue of capital by companies listed on any stock exchange in Bangladesh, should be subjected to some additional conditions (SEC Notification, July 03, 2012).

Table 1. Disclosures related to bank governance.

\begin{tabular}{l|l|c}
\hline S.N. & Sub Index & Disclosure Items \\
\hline 1 & Board related information & 49 \\
\hline & Disclosures related to CFO, Head of Internal Audit and \\
& Company Secretary (CS) & 2 \\
\hline 3 & Audit Committee-related disclosures & 42 \\
\hline 4 & Audit (statutory) and accounts & 9 \\
\hline 5 & Subsidiary company related disclosure & 5 \\
\hline 6 & Disclosures related to the duties of the CEO and CFO & 4 \\
\hline 7 & Disclosures related to governance compliance & 2 \\
\hline Total Items & 113 \\
\hline
\end{tabular}

Table 1 shows the factors of corporate governance that are broadly classified under seven headings. The bank governance index is calculated based on the compliance and non-compliance of the 113 items. In constructing the index value, the compliance of any item is indicated by “1”, and “o” otherwise. We used simple average (unweighted average) to determine the bank governance index for each bank for each year.

Bank Governance Index $(B G I)=\frac{\sum_{i=1}^{n} \text { Governance Indices }_{i}}{N}$

\subsection{Other Control Variable}

2.4.1. Regulatory Capital (CAR)

Bank capital is used to raise profit, but capital acts as a buffer for the enterprise. Banks with higher regulatory capital are more capable of surviving the financial distress than banks with lower regulatory capital. Since 1996, Bangladesh has used risk-based capital adequacy in its annual reports, but Huang (2006) showed that banks reject risk-based capital adequacy in their annual reports. Indeed, complying with banking laws and regulations has attracted considerable interest since the 2010 financial crisis. In 2010, Bangladesh implemented the Basel II Financial Institute Capital Arrangement. Previous research showed a mixed outcome in the risk/capital adequacy 
ratio relationship. Capital adequacy ratio was found to have a positive effect on bank vulnerability, as risky banks sought to collect more capital (Altunbas, Carbo, Gardener, \& Molyneux, 2007; Laeven \& Levine, 2009; Lin, Penm, Gong, \& Chang, 2005; Rime, 2001), while other research (Agoraki, Delis, \& Pasiouras, 2011; Ho \& Hsu, 2010; Lee \& Hsieh, 2013; Lee \& Chih, 2013) found negative correlations.

\section{CREG $=\frac{\text { Tier } 1 \text { Capital }+ \text { Tier } 2 \text { Capital }}{\text { Risk Weighted Assets }}$}

\subsection{Bank Growth (GROWTH)}

The analysis uses asset growth as a control variable to demonstrate the impact of capital on the asset expansion ability of the bank. Shim (2013) conducted a US-based bank holding analysis. It showed that asset growth is correlated with bank capital buffer. In fact, the rise in assets adversely affected the capital cushion that was concurrently responsible for increasing overall risk. Asset growth is argued to behave adversely in the capital equation.

Moreover, many studies (Daily \& Dalton, 1994; Erkens et al., 2012; Manzaneque, Priego, \& Merino, 2016) revealed that business size was used as a control variable to quantify financial distress and forecast bank risk. It concludes that more small banks are hit by financial crises, while larger companies have more diversified portfolios (Miglani, Ahmed, \& Henry, 2015). Similar research by Amendola, Restaino, \& Sensini (2015) found that bank asset development adversely affected bank liquidation and defaults as the prospective investment judgment would be more effective, leading to lower credit danger.

$$
\text { GROWTH }=\frac{\left(\text { Assets }_{t}-\text { Assets }_{t-1}\right)}{\text { Assets }_{t}}
$$

\subsection{Bank Inefficiency (INEFFICIENCX)}

The interest expense measures bank inefficiency to interest income ratio. The reason is that banks operate to earn profit, which is the differential figure between interest income and expense. To ensure the quality of earnings, banks must rely on the core element of income rather than other sources. In this case, inefficiency shows lower interest income by the inefficient distribution of loans and advances out of total deposits. According to the "Bad Management" hypothesis, inefficiency is positively associated with the credit risk of a bank. A possible cause is an increase of non-performing loans, which silently reduces any future earnings. Kwan \& Eisenbeis (1997), Altunbas et al. (2007), and Agusman, Monroe, Gasbarro, \& Zumwalt (2008) found that inefficiency is positively related with risk-taking, which is also supported by the "Moral Hazard Hypothesis (MHH)."

\section{INEFFICIENCY $=\frac{\text { Operating Expenses }}{\text { Operating Income }}$}

\subsection{Income Diversification (DIVERSIFICATION)}

Wealth diversification is calculated by the non-operating income-to-total income ratio. In fact, banking is not only limited to interest revenue and interest expenditures, but also extends to other services used as sources of income (Chaibi \& Ftiti, 2015; Louzis, Vouldis, \& Metaxas, 2012). Banks with more sources of income are believed to be more diversified in revenue generation and can achieve results by increased production. It is also a risk diversification operation, improving bank efficiency with better capital adjustment. There is no indication of a correlation in prior studies between income diversification and bank risk. Shim's (2013) research revealed income 
diversification as a risk and capital model control variable where the impact was restricted by the author's assumption as the model's negative influence.

\section{DIVERSIFICATION $=\frac{\text { Non }- \text { Operating income }}{\text { Total Income }}$}

2.8. Bank Age (AGE)

Bank age showed the experiences obtained since the inception of the company. The research conducted by Miller \& Friesen (1984) revealed that companies cross the company life cycle started with their incorporation (stage of initiation) and ended with liquidation (decline stage). The corporate life cycle is defined in four distinct stages, i.e. introduction, expansion, maturity, and decay, where financial difficulty or bankruptcy is considered the fundamental cornerstone of this cycle (Wruck, 1990), and the whole time span is the age of the company. Several studies (Alves, Couto, \& Francisco, 2015; Bhimani, Gulamhussen, \& Lopes, 2010; Denis, Denis, \& Sarin, 1997; Miller \& Friesen, 1984) revealed that business age is the prevailing factor in the financial distress model and has a major impact on firm stability. The risk of bankruptcy is affected by many bank-level variables, i.e. size, age, and debt, where aged companies have an inverse relationship with liquidation (Amendola et al., 2015). Overall, company age and scale are favorably correlated with financial instability or liquidation, as large companies will ultimately handle all soughtafter risks adequately and follow the "too-big-to-fail (TBTF)" theory. The dispute exposed by Bhimani et al. (2010) showed that there is an inverse association between age and default risk as seasoned and bigger companies have more leverage to negotiate with the debt issuer and are more financially sound due to their business expertise. Centered on the aforementioned discussion, the transparency and governance model used bank age as a control variable.

\section{$A G E=$ Inception Date to Sample Year}

\subsection{Stock Market Development (STOCKder)}

The ratio of stock market capitalization to gross domestic product is determined (GDP). Tan \& Floros (2013) used this variable in their studies on the Chinese banking industry focusing on market strength, efficiency, and bank stability. The study showed that stock market growth is adversely correlated with the market control of China's banks. The explanation for this is that the established capital exchange offers options for listed companies to collect funds by selling securities rather than debt funding. The result has intensified consumer competition to attract new customers by providing conventional and non-traditional offerings. Indeed, borrowers and lenders are deteriorating at this point. It also showed that stock market growth is favorably correlated with market power, as the open market place also enhances influence by offering more market knowledge and good governance. Maudos \& Nagore (2005) showed that proper income diversification, particularly in non-interest income, increases banks' superiority and helps them to enjoy market strength. However, there is no substantial evidence in the transparency and corporate governance model of stock market growth, but this analysis uses the indicator as a control variable and assumes that there is an association between the variables.

$$
\text { STOCKdev }=\frac{\text { Stock Market Capitalization }}{\text { GDP }} \times 100
$$

\subsection{GDP Growth Rate (GDPgrowth)}

GDP growth rate is the macroeconomic predictor of a country's progress. This element is used in both models as a macroeconomic indicator related to the stock market. Several studies (Bikker \& Metzemakers, 2004; Jokipii \& Milne, 2008; Stolz \& Wedow, 2011) got mixed results (both positive and negative) from the capital model. It is 
believed that the banking sector takes less risk in higher economic growth, so any desired negative externality cannot impact bank output. Conversely, if the GDP growth rate rises, businessmen take out fewer loans since they have ample funding, and consequently, the banks struggle due to liquidity and lower their lending rates. The relation can be positional or derogatory, but both have rational grounds. GDP growth is presumed to have a positive relationship with bank performance and vice versa with risk-taking behavior (Pasiouras \& Kosmidou, 2007).

\section{GDP growth $=$ Annual Real GDP Growth rate}

\subsection{Inflation Rate (INFER)}

Inflation is the macroeconomic measure representing money's buying power. The analysis uses this attribute to manage all models. A previous study by Tan \& Floros (2013) considered Chinese market strength, efficiency, and financial stability, and found a strong correlation between inflation rate and market power in banks. Conversely, Zheng \& Shen (2008) found that inflation rate is adversely correlated with bank default risk due to people's reluctance to take out bank loans, and lower credit default performance. It also disclosed that inflation rate positively influences banks' risk-taking behavior (Hussain \& Hassan, 2005). Lee \& Hsieh (2013) proposed charging lenders more by imposing interest on the inflationary situation. The explanation is that the banks wanted to cover up their gains by hiking interest rates as inflation rose. Finally, Chaibi \& Ftiti (2015) published their studies which found both positive and negative correlation between inflation and bank risk.

\section{INFER = Annual Inflation rate}

\section{METHODOLOGY}

This current study investigates the banks' risk-taking behavior and examines the hypothesis of its determinants and consequences. The data related to bank risk, its determinants, and consequences was collected from annual reports, which were downloaded from the DSE and the relevant banks' websites.

\subsection{Data and Sample}

The data sets are constructed based on panel data consisting of 11 years' worth of time series data from 2008 to 2018 and 32 commercial banks' longitudinal data. The total number of observations is 346 . In 2009 , there were 48 banks operating in Bangladesh consisting of four categories of scheduled banks: national commercial banks (NCBs), development finance institutions (DFIs), private commercial banks (PCBs) and foreign commercial banks (FCBs). The structure of the banking sector with a breakdown by type of bank is shown in Figure 3 below.

\section{Number of Bank Branches}

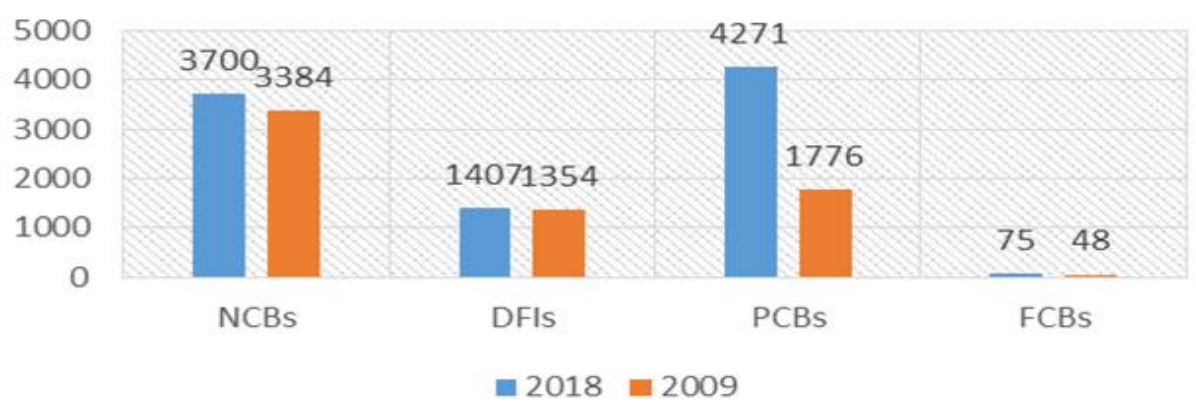

Figure 3. Comparative scenario by types of banks. 


\subsection{Model Selection}

This study considered prior research to formulate the model. The endogeneity of explanatory variables determines simultaneity. Explanatory variables and independent variables were mutually calculated in this case by equilibrium. The classic SEM model is as follows:

$$
\begin{aligned}
& \text { BLR }_{i, t}=\alpha_{0}+\alpha_{1} \text { FDI }_{i, t}+\alpha_{2} \text { BGI }_{i, t}+\alpha_{3}\left(\text { FDI }_{i, t} * \text { BGI }_{i, t}\right)+\alpha_{4} \text { CAR }_{i t}+\alpha_{5} \text { GROWTH }_{i, t}+ \\
& \alpha_{6} \text { INEFFICIENCY }_{i, t}+\alpha_{7} \text { DIVERSIFICATION }_{i, t}+\alpha_{8} \text { GDPgrowth }_{i, t}+\alpha_{9} \text { INFER }_{i, t}+\varepsilon_{i, t}
\end{aligned}
$$

$F D I_{i, t}=\beta_{0}+\beta_{1} B L R_{i t}+\beta_{2} B G I_{i, t}+\beta_{3} G R O W T H_{i, t}+\beta_{4} A G E_{i, t}+\beta_{5} S T O C K \operatorname{dev} i_{i, t}+$

$\beta_{6}$ GDPgrowth $_{i, t}+\beta_{7}$ INFER $_{i t}+\varepsilon_{i, t}$

$B G I_{i, t}=\beta_{0}+\beta_{1} B L R_{i t}+\beta_{2} F D I_{i, t}+\beta_{3}$ GROWTH $_{i, t}+\beta_{4} A G E_{i, t}+\beta_{5}$ STOCKdev $_{i, t}+$

$\beta_{6}$ GDP growth $_{i, t}+\beta_{7}$ INFER $_{i t}+\varepsilon_{i, t}$

$\mathcal{E}_{i t}=v_{i t}+u_{i t}$

BLR $=$ Bank Liquidity Risk.

FDI $=$ Financial Disclosure Index.

BGI = Bank Governance Index.

CAR $=$ Capital Adequacy Ratio.

GROWTH = Bank Growth Rate.

INEFFICIENCY = Bank Inefficiency.

DIVERSIFICATION = Income Diversification.

GDPgrowth = GDP Growth Rate.

INFER = Inflation Rate.

AGE $=$ Bank Age.

STOCKdev $=$ Stock Market Development.

$\mathrm{i}=$ Cross Section

$\mathrm{t}=$ Time Periods.

Where " $i$ " denotes the cross-sectional dimension across banks and " $\mathrm{t}$ " denotes the time dimension. It is the random error concept, with $\mathrm{v}_{\mathrm{it}}$ capturing the unobserved bank unique effect and $\mathrm{u}_{\mathrm{it}}$ denoting the idiosyncratic error, which is individually and identically distributed (i.i.d), $e_{i t} \mathrm{~N}(0,2)$. Equations 1,2 and 3 investigate whether transparency, governance, and the multiple effects of disclosure and governance can represent shifts in banks, as well as liquidity risk.

\subsection{Preliminary Diagnosis}

\subsubsection{Unit Root Test}

In recent years, panel data unit root tests have gained popularity. It is argued that this is one method of obtaining further insights and addressing the unit root test's low power dilemma. The Levin-Lin (LL) tests are the most widely used, followed by the Im-Pesaran-Shin (IPS) and Maddala-Wu (MW) tests.

In Levin-Lin (LL) test, the data stationary is checked by the hypothesis by:

$\mathrm{H}_{0}$ : contain unit roots

$\mathrm{H}_{1}$ : Panels are stationary

A unit root test is used in statistics to assess whether a component is stationary or non-stationary and if it has a unit root. The lack of a unit root is the null hypothesis, while stationarity is the alternate hypothesis. Many of the variables in Table 2 are stationary and are therefore suitable for further processing. 
Table 2. Data stationarity (Levin-Lin-Chu unit root) test.

\begin{tabular}{l|l}
\hline Variable & Decision \\
\hline BLR1 & Stationary at level \\
\hline BLR2 & Stationary at level \\
\hline FDI & Stationary at level \\
\hline BGI & Stationary at level \\
\hline FDI*BGI & Stationary at level \\
\hline CAR & Stationary at level \\
\hline GROWTH & Stationary at level \\
\hline INEFFICIENCY & Stationary at level \\
\hline DIVERSIFICATION & Stationary at level \\
\hline AGE & Stationary at level \\
\hline STOCKdev & Stationary at level \\
\hline GDPgrowth & Stationary at level \\
\hline INFER & Stationary at level \\
\hline Note: Adjusted t-value. &
\end{tabular}

\subsubsection{Test of Endogeneity}

The problem of endogeneity is caused by two main factors - uncontrolled confounding that affects both independent and dependent variables, and simultaneity between the model's independent and dependent variables. It actually deals with the case where the explanatory variable and the error parameter are associated. Measurement error, autoregression with autocorrelated errors, simultaneous causality, and omitted variables all contribute to this problem. The study used an endogeneity measure in the analysis to ensure that the variables were all in the same place at the same time. The findings of our study (see Table 3) refute the null hypothesis that the variables are exogenous, confirming the endogeneity issue. The $\mathrm{Wu}-$ Hausman endogeneity test revealed statistical importance in Equation 1 at a 5\% level, and in Equation 2 at a $1 \%$ level.

Table 3. Tests of endogeneity for liquidity risk, disclosures, and governance model.

\begin{tabular}{c|c|c|c|c|c|c|c|c}
\hline \multicolumn{4}{c|}{ Ho: Variables are exogenous. } & \multicolumn{3}{c}{ H1: Variables are endogenous. } \\
\hline & \multicolumn{3}{c|}{ Liquidity Risk } & Bank Disclosures & \multicolumn{2}{c}{$\begin{array}{c}\text { Corporate } \\
\text { Governance }\end{array}$} \\
\hline & Model 1 & Model 2 & Model 3 & Model 4 & Model 5 & Model 6 & $\begin{array}{c}\text { Model } \\
\mathbf{7}\end{array}$ & Model 8 \\
\hline Difference in J-stats & 8.9667 & 10.0587 & 8.9133 & 20.9564 & 13.33674 & 8.428019 & 9.6517 & 8.8560 \\
\hline Probability & 0.0027 & 0.0015 & 0.0028 & 0.0000 & 0.0003 & 0.0037 & 0.0019 & 0.0029 \\
\hline
\end{tabular}

\subsubsection{Test of Heteroskedasticity}

When the variance of the unobservable error $\mathrm{u}_{\mathrm{i}}$, based on independent variables, is not constant, i.e., $\operatorname{Var}\left(u_{i} / X_{i}\right)=\sigma_{i}^{2}$, heteroskedasticity is said to exist. In particular, the variance of the error can be a function of independent variables:

$$
\operatorname{Var}\left(u_{i} / X_{i}\right)=\sigma^{2} h\left(X_{i}\right) \text {. }
$$

The White test is designed to look for heteroskedasticity in the following ways: the relationship between u2 and all independent variables $\left(X_{i}\right)$, the squares of $i^{\text {th }}$ independent variables $\left(\boldsymbol{X}_{i}^{2}\right)$, and all cross products $\left(X_{i} X_{j}\right.$ for $\left.i \neq j\right)$. Table 4 shows that the error term $u_{i}$ is homoskedastic and is rejected by all equations in the model. Both Equations 1 and 2 are statistically valid at the $1 \%$ and $5 \%$ levels, respectively. 
Table 4. Heteroskedasticity test for liquidity risk, disclosure, and governance model.

\begin{tabular}{|c|c|c|c|c|c|c|c|c|}
\hline \multicolumn{9}{|c|}{ Heteroskedasticity Test: White } \\
\hline \multicolumn{5}{|c|}{$\mathbf{H}_{\mathrm{o}}$ : Errors are homoskedastic. } & \multicolumn{4}{|c|}{$\mathbf{H}_{1}$ : Errors are heteroskedastic. } \\
\hline & \multicolumn{4}{|c|}{ Liquidity Risk } & \multicolumn{2}{|c|}{ Bank Disclosure } & \multicolumn{2}{|c|}{$\begin{array}{c}\text { Corporate } \\
\text { Governance }\end{array}$} \\
\hline & Model 1 & Model 2 & Model 3 & Model 4 & Model 5 & Model 6 & Model 7 & Model 8 \\
\hline F-statistic & 172.4051 & 62.72438 & 14.38931 & 40424.44 & 2.686716 & 1.125456 & Model & 362.4985 \\
\hline Prob. $\mathrm{F}(35,310)$ & 0.0000 & 0.0000 & 0.0000 & 0.0000 & 0.0000 & 0.2939 & 126.2167 & 0.0000 \\
\hline Obs* $\mathrm{R}^{2}$ & 335.5128 & 318.6257 & 96.25765 & 345.9539 & 80.52800 & 39.00865 & 0.0000 & 340.9317 \\
\hline $\begin{array}{ll}\text { Prob. } & \text { Chi- } \\
\text { Square(35) } & \end{array}$ & 0.0000 & 0.0000 & 0.0000 & 0.0000 & 0.0000 & 0.2942 & 331.8322 & 0.0000 \\
\hline $\begin{array}{l}\text { Scaled explained } \\
\text { SS }\end{array}$ & 656.9604 & 492.2892 & 126.3046 & 450.5808 & 115.0739 & 78.48468 & 0.0000 & 629.9078 \\
\hline $\begin{array}{ll}\text { Prob. } & \text { Chi- } \\
\text { Square(35) } & \end{array}$ & 0.0000 & 0.0000 & 0.0000 & 0.0000 & 0.0000 & 0.0000 & 576.3016 & 0.0000 \\
\hline
\end{tabular}

\subsubsection{Test of Autocorrelation}

If $\operatorname{Cov}\left(u_{i}, u_{j}\right) \neq 0$, for $i \neq \mathrm{j}$, the error terms are said to be autocorrelated. The Breusch-Godfrey test was used to determine if there is serial overlap. The concept behind this test comes from the Lagrange multiplier, known as the LM test for serial correlation. The equations are statistically valid $(\mathrm{p}<0.05)$ and deny the null hypothesis that there is no serial association with the error term (see Table 5).

Table 5. Serial correlation test for liquidity risk, disclosure, and governance model.

\begin{tabular}{|c|c|c|c|c|c|c|c|c|}
\hline \multicolumn{9}{|c|}{ Breusch-Godfrey Serial Correlation LM Test } \\
\hline \multicolumn{5}{|c|}{$\mathrm{H}_{0}:$ There is no serial correlation } & \multicolumn{4}{|c|}{$\mathrm{H}_{1}$ : There is serial correlation } \\
\hline & \multicolumn{4}{|c|}{ Liquidity Risk } & \multicolumn{2}{|c|}{ Bank Disclosure } & \multicolumn{2}{|c|}{$\begin{array}{c}\text { Corporate } \\
\text { Governance }\end{array}$} \\
\hline & Model 1 & Model 2 & Model 3 & Model 4 & Model 5 & Model 6 & Model 7 & Model 8 \\
\hline $\mathrm{Obs}^{*} \mathrm{R}^{2}$ & 181.6789 & 121.4678 & 155.7763 & 155.2754 & 155.6111 & 172.2421 & 119.9581 & 176.1632 \\
\hline $\begin{array}{l}\text { Prob. Chi- } \\
\text { Square (2) }\end{array}$ & 0.0000 & 0.0000 & 0.0000 & 0.0000 & 0.0000 & 0.0000 & 0.0000 & 0.0000 \\
\hline
\end{tabular}

\subsubsection{Fixed Effect vs. Random Effect}

The fixed effect (FE) model is used to examine the influence of time-varying variables. It aids in the regulation of predictor or outcome variable bias. This model is commonly regarded as a more reliable method for estimating ceteris paribus impacts (Wooldridge, 2006). The time-invariant characteristics are normally removed from the FE model before assessing the net effect on the outcome variable.

When time-invariant variables become peculiar to an entity, they cannot be compared with the characteristics of others. When the error terms of the entities are correlated, the random effect (RE) is supported. When the primary explanatory variable remains unchanged over time, the random effect model is used. The choice of fixed effect or random effect is ultimately determined by the Hausman test.

The research ran regressions using both the fixed and random effect in the risk model and found the fixed effect model to be sufficient, as it was statistically relevant at the $1 \%$ stage, according to the Hausman test.

In the context of the disclosure model, the Hausman test was used to diagnose fixed effect and random effect models in order to choose the right model for the given scenario. The fact that the outcome of the disclosure model was less than $5 \%(\mathrm{p}<5 \%)$ indicates that a fixed effect model rather than a random effect model is sufficient, implying that the alternative hypothesis is adopted. 
In the case of the governance model, the study found a similar result where the fixed effect model is supported and also significant at the $5 \%$ level. The study showed a similar finding in the government model, where the fixed effect model is endorsed and relevant at the $5 \%$ level.

\subsection{Data Processing Methods}

The preliminary diagnosis reveals that the model is restricted in using the ordinary least squares (OLS) regression model. The phenomenon is very common in panel data analysis. It was found that the existence of an endogeneity problem severely affects the regression results. Furthermore, heteroskedasticity and autocorrelation problems were also found in the model. Therefore, the probable solution for solving these issues is the two-stage least squares (2SLS) regression method for the data analysis to obtain accurate statistical results.

\section{ANALYSIS AND FINDINGS}

The descriptive statistics are detailed in Table 6. It was found that the dependent variable of bank liquidity risk has a greater standard deviation in BLR2. The FDI, BGI, and the multiple effect of FDI*BGI has a lower deviation and a consistent mean value. The results of the other control variables are summarized below:

Table 6. Descriptive statistics.

\begin{tabular}{c|c|c|c|c|c}
\hline & $\mathbf{N}$ & Minimum & Maximum & Mean & Std. Deviation \\
\hline BLR 1 & 346 & 0.37 & 1.12 & 0.83 & 0.11 \\
\hline BLR 2 & 346 & 32.18 & 83.75 & 66.85 & 8.52 \\
\hline FDI & 346 & 0.52 & 1.00 & 0.88 & 0.11 \\
\hline BGI & 346 & 0.70 & 1.00 & 0.96 & 0.07 \\
\hline FDI*BGI & 346 & 0.50 & 1.00 & 0.85 & 0.13 \\
\hline CAR & 346 & -17.58 & 20.92 & 11.34 & 3.03 \\
\hline GROWTH & 346 & 0.00 & 66.69 & 9.37 & 9.88 \\
\hline DIVERSIFICATION & 346 & 17.85 & 112.23 & 44.20 & 2.69 \\
\hline AGE & 346 & 2.96 & 56.43 & 27.29 & 9.28 \\
\hline STOCKdev & 346 & 5.00 & 44.00 & 20.11 & 10.09 \\
\hline GDPgrowth & 346 & 4.81 & 34.33 & 19.87 & 8.50 \\
\hline INFER & 346 & 5.05 & 7.11 & 6.28 & 0.59 \\
\hline
\end{tabular}

\subsection{The Effects of Bank Disclosure, Corporate Governance, and Bank Liquidity Risk}

The study used total loan and advance to total deposits (TLATD), and total loan and advance to total assets (TLATA) as a proxy of bank liquidity risk. The most important function of banks is collecting deposits and granting loans. The profit generated for the banks is the differential figure of interest earned on granting loans and interest paid on deposit collection. Thus, the position of liquidity is preferable in the condition where TLA < TD, but the reversal position (TLA > TD) is risky where additional money injected into the investment channel by manipulation or violation of existing theories.

From the results in Table 7, we can see that financial disclosure index (FDI), bank governance index (BGI), and the multiplier effects of disclosures and governance (FDI*BGI) have a negative effect on bank liquidity risk. It indicates that a higher level of liquidity risk demands more disclosure and a strong governance system in the marketplace. The situation is widespread and is similar to the contemporary consequences found in Bangladesh. In the last quarter of 2017, one newly established bank (a fourth generation bank) was Farmers Bank Ltd. They encountered a severe liquidity crisis due to their aggressive lending policy where they experienced more than $700 \%$ of non-performing loans (for the last quarter) and circulated a notice to the public that they are in a liquidity crisis and are not able to pay the deposits for the next few months. After that, they sent a message to their employees to inform them that they won't be paying their salaries or allowances for the next few months. At that time, the chairman of the bank and the auditor resigned from their posts due to their inefficiencies and corruption. The 
evidence here supports the claim that risky banks should be more transparent and have strong governance systems to tackle risks. Among the bank level variables, CAR, GROWTH, and INEFFICIENCY have negative impacts on bank liquidity risk, whereas DIVERSIFICATION has a positive impact. For the macroeconomic variables, both GDPgrowth and INFER have positive but insignificant impacts on bank liquidity risk.

Table 7. Effect of bank disclosure and governance on bank liquidity risk (BLR 1 ).

\begin{tabular}{|c|c|c|c|c|}
\hline & \multicolumn{4}{|c|}{ BLR1 } \\
\hline & Model I & Model II & Model III & Model IV \\
\hline \multirow[t]{2}{*}{ FDI } & $-0.0009^{* *}$ & $-0.0481^{* *}$ & & \\
\hline & $(0.0671)$ & $(0.0649)$ & & \\
\hline \multirow[t]{2}{*}{ BGI } & $-0.1015 * * *$ & & $-0.1026 * * *$ & \\
\hline & $(0.0402)$ & & $(0.0426)$ & \\
\hline \multirow[t]{2}{*}{ FDI*BGI } & & & & $-0.0721^{* *}$ \\
\hline & & & & $(0.0408)$ \\
\hline \multirow[t]{2}{*}{ CAR } & -0.0008 & -0.0007 & -0.0008 & -0.0008 \\
\hline & $(0.0006)$ & $(0.0006)$ & $(0.0005)$ & $(0.0006)$ \\
\hline \multirow[t]{2}{*}{ GROWTH } & -0.0004 & -0.0003 & -0.0004 & -0.0007 \\
\hline & $(0.0007)$ & $(0.0007)$ & $(0.0006)$ & $(0.0007)$ \\
\hline \multirow[t]{2}{*}{ INEFFICIENCY } & $-0.0016^{* * * *}$ & $-0.0016^{* * *}$ & $-0.0016^{* * *}$ & $-0.0016^{* * * *}$ \\
\hline & $(0.0003)$ & $(0.0003)$ & $(0.0003)$ & $(0.0003)$ \\
\hline \multirow[t]{2}{*}{ DIVERSIFICATION } & 0.0009 & 0.0008 & 0.0008 & 0.0008 \\
\hline & $(0.0009)$ & $(0.0009)$ & $(0.0009)$ & $(0.0009)$ \\
\hline \multirow[t]{2}{*}{ GDPgrowth } & 0.0079 & 0.0076 & 0.0080 & 0.0085 \\
\hline & $(0.0081)$ & $(0.0081)$ & $(0.0082)$ & $(0.0079)$ \\
\hline \multirow[t]{2}{*}{ INFER } & 0.0062 & 0.0069 & 0.0061 & 0.0058 \\
\hline & $(0.0058)$ & $(0.0056)$ & $(0.0061)$ & $(0.0062)$ \\
\hline \multirow[t]{2}{*}{ CONST } & $0.7007^{* * * *}$ & $0.7505^{* * * *}$ & $0.7006^{* * * *}$ & $0.7421^{* * * *}$ \\
\hline & $(0.1048)$ & $(0.0977)$ & (0.0909) & $(0.0826)$ \\
\hline No. of Banks & 32 & 32 & 32 & 32 \\
\hline Observations & 346 & 346 & 346 & 346 \\
\hline Adj. $\mathrm{R}^{2}$ & $70.50 \%$ & $70.52 \%$ & $70.60 \%$ & $70.60 \%$ \\
\hline F-Value & $22.1413^{* * *}$ & $22.6918^{* * * *}$ & $22.8005^{* * *}$ & $22.710^{* * * *}$ \\
\hline Hansen J stat. (overid test) & 0.8263 & 0.8400 & 0.8399 & 0.6131 \\
\hline
\end{tabular}

Table 8 shows that the financial disclosure index (FDI) has a negative and significant p-value $(\mathrm{P}<0.01)$ effect on liquidity risk in Models V and VI with coefficients of -31.0969 and -24.6290, respectively. This indicates that bank disclosure reduces the risk-taking behavior of banks as the public is more concerned about risk, and the market response is immediately adjusted by current and past information. On the other hand, the corporate governance index has a positive effect on bank risk, meaning that a strong governance system is necessary for risky banks to protect themselves from liquidation. The independent variable FDI*BGI in Model VIII showed a negative and significant impact on bank liquidity risk. For the bank level variables, CAR, INEFFICIENCY, and DIVERSIFICATION showed negative effects on bank liquidity risk, whereas GROWTH had a positive and significant effect. For the macroeconomic variable, GDP growth had a negative effect on liquidity risk, whereas INFER had a positive impact, but both are statistically insignificant.

Table 9 shows the reversal effect of liquidity risk on the bank disclosure index. The study found that liquidity risk, both BLR1 and BLR2, has a positive effect on bank disclosure. It indicates that more disclosure practices lessen the liquidity risk, whereas a higher risk is a result of irregular or lower disclosure. Among bank-level variables, only the bank governance index (BGI) had a negative impact on bank disclosure, but the other variables (GROWTH and AGE) had positive and significant $(\mathrm{P}<0.01)$ effects. The industry level variable, STOCKdev had a positive impact on bank disclosure and was also significant at the $1 \%$ level. The macroeconomic variables of both GDPgrowth and INFER were statistically significant in Models IX and X. It was found that GDPgrowth had a positive effect on disclosure with coefficients of 0.0909 and 0.00894 but INFER had an adverse impact. 
Table 8. Effect of bank disclosure and governance on bank liquidity risk (BLR1)

\begin{tabular}{|c|c|c|c|c|}
\hline & \multicolumn{4}{|c|}{ BLR2 } \\
\hline & Model V & Model VI & Model VII & Model VIII \\
\hline \multirow[t]{2}{*}{ FDI } & $-31.0969^{* * *}$ & $-24.6290^{* * * *}$ & & \\
\hline & $(4.9565)$ & $(4.8243)$ & & \\
\hline \multirow[t]{2}{*}{ BGI } & $-12.5602 * * *$ & & $-4.4739 * *$ & \\
\hline & $(3.2121)$ & & $(3.4718)$ & \\
\hline \multirow[t]{2}{*}{ FDI*BGI } & & & & $-15.2021^{* * * *}$ \\
\hline & & & & $(3.1568)$ \\
\hline \multirow[t]{2}{*}{ CAR } & $-0.3296^{* * *}$ & $-0.3151^{* * *}$ & $-0.3345^{* * * *}$ & $-0.3065^{* * * *}$ \\
\hline & $(0.0784)$ & $(0.0774)$ & $(0.1126)$ & (0.0819) \\
\hline \multirow[t]{2}{*}{ GROWTH } & $0.0673^{* *}$ & $0.0729 * *$ & $0.1270^{* *}$ & $0.0477^{*}$ \\
\hline & $(0.0350)$ & $(0.0345)$ & (0.0569) & $(0.0292)$ \\
\hline \multirow[t]{2}{*}{ INEFFICIENCY } & $-0.0994^{* * * *}$ & $-0.0975^{* * *}$ & $-0.1336^{* * *}$ & $-0.1001^{* * *}$ \\
\hline & (0.0197) & (0.0199) & $(0.0250)$ & $(0.0219)$ \\
\hline \multirow[t]{2}{*}{ DIVERSIFICATION } & -0.0168 & -0.0170 & -0.0258 & -0.0111 \\
\hline & $(0.0578)$ & (0.0599) & $(0.0501)$ & (0.0599) \\
\hline \multirow[t]{2}{*}{ GDPgrowth } & -0.4457 & -0.5018 & -0.2900 & -0.3964 \\
\hline & $(0.6324)$ & $(0.6487)$ & $(0.5291)$ & $(0.6638)$ \\
\hline \multirow[t]{2}{*}{ INFER } & 0.3740 & 0.3893 & 0.0179 & 0.3206 \\
\hline & $(0.4793)$ & $(0.4930)$ & $(0.6107)$ & $(0.5449)$ \\
\hline \multirow[t]{2}{*}{ CONST } & $90.4657^{* * * *}$ & $96.7719^{* * * *}$ & $72.4498^{* * * *}$ & 87.8407 **** \\
\hline & $(8.9751)$ & $(8.2799)$ & $(6.0775)$ & $(7.5944)$ \\
\hline No. of banks & 32 & 32 & 32 & 32 \\
\hline Observations & 346 & 346 & 346 & 346 \\
\hline Adj. $\mathrm{R}^{2}$ & $77.80 \%$ & $78.28 \%$ & $77.01 \%$ & $77.67 \%$ \\
\hline F-value & $36.1062^{* * * *}$ & $36.5480^{* * * *}$ & $31.4084^{* * * *}$ & $36.4099^{* * * *}$ \\
\hline Hansen J stat. (overid test) & 0.7318 & 0.6751 & 0.5902 & 0.7411 \\
\hline
\end{tabular}

Note: ${ }^{* * *},{ }^{*}$, and $*$ indicate significance at $1 \%, 5 \%$, and $10 \%$ levels, respectively.

Table 9. The effect of liquidity risk on bank disclosure.

\begin{tabular}{|c|c|c|}
\hline & \multicolumn{2}{|c|}{ FDI } \\
\hline & Model IX & Model X \\
\hline \multirow[t]{2}{*}{ BLR1 } & $0.01950^{* *}$ & \\
\hline & (0.03200) & \\
\hline \multirow[t]{2}{*}{$\mathrm{BLR} 2$} & & $0.00024^{* *}$ \\
\hline & & $(0.00035)$ \\
\hline \multirow[t]{2}{*}{ BGI } & $-0.12130^{*}$ & $-0.12255^{*}$ \\
\hline & $(0.05094)$ & (0.04969) \\
\hline \multirow[t]{2}{*}{ GROWTH } & $0.00112 * * *$ & $0.00114 * * *$ \\
\hline & $(0.00016)$ & $(0.00017)$ \\
\hline \multirow[t]{2}{*}{$\mathrm{AGE}$} & $0.00175^{* * *}$ & $0.00175^{* * *}$ \\
\hline & $(0.00020)$ & $(0.00019)$ \\
\hline \multirow[t]{2}{*}{ STOCKdev } & $0.01715^{*} * *$ & $0.01703 * * *$ \\
\hline & $(0.00102)$ & (0.00094) \\
\hline \multirow[t]{2}{*}{ GDPgrowth } & $0.00909 * * *$ & $0.00894^{* * * *}$ \\
\hline & $(0.00179)$ & $(0.00180)$ \\
\hline \multirow[t]{2}{*}{ INFER } & $-0.01874^{* * * *}$ & $-0.01871^{* * * *}$ \\
\hline & $(0.00166)$ & $(0.00173)$ \\
\hline \multirow[t]{2}{*}{ CONST } & 0.68197 *** & $0.68635^{* * * *}$ \\
\hline & $(0.03569)$ & $(0.04637)$ \\
\hline No. of banks & 32 & 32 \\
\hline Observations & 346 & 346 \\
\hline Adj. $\mathrm{R}^{2}$ & $83.57 \%$ & $83.53 \%$ \\
\hline F-value & $47.1790 * * *$ & $47.0294 * * *$ \\
\hline Sargan test & 0.4591 & 0.4548 \\
\hline
\end{tabular}

Note: ***, **, and $*$ indicate significance at $1 \%, 5 \%$, and $10 \%$ levels, respectively

The most valued factor of banks is a good governance policy that establishes the tone of the organization. Here, the study showed the effect of liquidity risk on bank governance system. It was found that the liquidity risks, 
expressed as TLATD and TLATA, had a positive impact on the corporate governance index and were also statistically significant at 5\% and 10\% levels (as shown in Table 10). It indicates that higher risk puts pressure on banks to establish strong government policies to avoid unexpected situations. For the bank level variable, the disclosure index negatively affected the governance system; this doesn't indicate weak governance but rather the urgency of producing and providing more information to shareholders. Other bank level variables, GROWTH and AGE, had positive and significant $(\mathrm{P}<0.01)$ effects on the bank governance system. The industry level variable, STOCKdev had a positive effect on governance and was also statistically significant at the $1 \%$ level. The macroeconomic variable, GDPgrowth, had a positive effect on bank liquidity risk, whereas INFER had a negative effect, but both were statistically significant at the $1 \%$ level.

Table 10. The effect of liquidity risk on corporate governance.

\begin{tabular}{|c|c|c|}
\hline & \multicolumn{2}{|c|}{ BGI } \\
\hline & Model XI & Model XII \\
\hline \multirow[t]{2}{*}{ BLR1 } & $0.02475^{* *}$ & \\
\hline & $(0.01160)$ & \\
\hline \multirow[t]{2}{*}{$\mathrm{BLR} 2$} & & $0.00045^{* *}$ \\
\hline & & $(0.00017)$ \\
\hline \multirow[t]{2}{*}{ FDI } & $-0.08028^{*}$ & $-0.08553 *$ \\
\hline & $(0.04824)$ & $(0.04764)$ \\
\hline \multirow[t]{2}{*}{ GROWTH } & $0.00117^{* * * *}$ & $0.00116^{* * * *}$ \\
\hline & $(0.00027)$ & $(0.00025)$ \\
\hline \multirow[t]{2}{*}{$\mathrm{AGE}$} & $0.00041^{* * * *}$ & $0.00044 * * *$ \\
\hline & $(0.00011)$ & $(0.00011)$ \\
\hline \multirow{2}{*}{ STOCKdev } & $0.00778^{* * * *}$ & $0.00807^{* * * *}$ \\
\hline & $(0.00116)$ & $(0.00113)$ \\
\hline \multirow[t]{2}{*}{ GDPgrowth } & $0.00583^{* * *}$ & 0.00595 *** \\
\hline & $(0.00121)$ & (0.00129) \\
\hline \multirow[t]{2}{*}{ INFER } & $-0.01614^{* * * *}$ & $-0.01627^{* * * *}$ \\
\hline & $(0.00206)$ & $(0.00222)$ \\
\hline \multirow[t]{2}{*}{ CONST } & $0.89710^{* * * *}$ & $0.88629^{* * * *}$ \\
\hline & $(0.02409)$ & $(0.02889)$ \\
\hline No. of banks & 32 & 32 \\
\hline Observations & 346 & 346 \\
\hline Adj. $\mathrm{R}^{2}$ & $61.73 \%$ & $62.24 \%$ \\
\hline F-value & $15.6422^{* * * *}$ & 15.9647 **** \\
\hline Sargan test & 0.9645 & 0.9508 \\
\hline
\end{tabular}

\section{CONCLUSION}

Liquidity problems may adversely affect a bank's earnings and capital. Under extreme circumstances, it may cause the collapse of an otherwise solvent bank. A bank with liquidity problems may experience difficulties in meeting the demands of depositors. However, this liquidity risk may be mitigated by maintaining sufficient cash reserves, raising its deposit base, and decreasing the liquidity gap and NPLs. Adequate cash reserves will decrease the bank's reliance on the repo market and this will reduce the cost associated with overnight borrowing. Moreover, it will also help the banks to avoid the risk of a fire sale.

It is imperative for management to be aware of the bank's liquidity position in different types of investment. This would improve their investment portfolios and give them a strategic advantage in the industry. The attention that a bank's management pays to liquidity issues is of the utmost importance. Any issues should be resolved as soon as possible, and urgent corrective action should be taken to prevent the repercussions of illiquidity.

This study paves the way for more detailed studies on controlling liquidity risk and provides the potential to extend the proposed model to incorporate other causes of liquidity. The current study has focused primarily on the 
earnings of the bank as a measure of its performance, so further research can take a broader view of the performance and also include economic factors.

Funding: This study received no specific financial support.

Competing Interests: The authors declare that they have no competing interests

Acknowledgement: Both authors contributed equally to the conception and design of the study.

\section{REFERENCES}

Adina, P., \& Ion, P. (2008). Aspects regarding corporate mandatory and voluntary disclosure. Annals of Faculty of Economics, 3, 1407-1411.

Agoraki, M.-E. K., Delis, M. D., \& Pasiouras, F. (2011). Regulations, competition and bank risk-taking in transition countries. Journal of Financial Stability, 7(1), 38-48.

Agusman, A., Monroe, G. S., Gasbarro, D., \& Zumwalt, J. K. (2008). Accounting and capital market measures of risk: Evidence from Asian banks during 1998-2003. Journal of Banking \& Finance, 32(4), 480-488. doi: https://doi.org/10.1016/j.jbankfin.2006.06.018

Ali, S. S. (2004). Islamic modes of finance and associated liquidity risks. Paper presented at the Paper Presented at the conference on Monetary Sector in Iran: Structure, Performance \& Challenging Issues, February, Tehran, Iran.

Altman, E. I. (1968). Financial ratios, discriminant analysis and the prediction of corporate bankruptcy. The Journal of Finance, 23(4), 589-609. doi: https://doi.org/10.1111/j.1540-6261.1968.tbo0843.x

Altunbas, Y., Carbo, S., Gardener, E. P., \& Molyneux, P. (2007). Examining the relationships between capital, risk and efficiency in European banking. European Financial Management, 13(1), 49-70. doi: https://doi.org/10.1111/j.1468036x.2006.00285.x

Alves, P., Couto, E. B., \& Francisco, P. M. (2015). Board of directors' composition and capital structure. Research in International Business and Finance, 35, 1-32. doi: https://doi.org/10.1016/j.ribaf.2015.03.005

Amendola, A., Restaino, M., \& Sensini, L. (2015). An analysis of the determinants of financial distress in Italy: A competing risks approach. International Review of Economics \& Finance, 37, 33-41. doi: https://doi.org/10.1016/j.iref.2014.10.012

Baumann, U., \& Nier, E. (2004). Disclosure, volatility, and transparency: An empirical investigation into the value of bank disclosure. Economic Policy Review, 10(2), 31-45.

Beaver, W. H. (1966). Financial ratios as predictors of failure. Journal of Accounting Research, 4, 71-111. doi: https://doi.org/10.2307/2490172

Beltratti, A., \& Stulz, R. M. (2012). The credit crisis around the globe: Why did some banks perform better? . Journal of Financial Economics, 105(1), 1-17. doi: https://doi.org/10.1016/j.jfineco.2011.12.005

Berger, A. N., \& Bouwman, C. H. (2009). Bank liquidity creation. The Review of Financial Studies, 22(9), 3779-3837.

Berger, A. N., Kick, T., \& Schaeck, K. (2014). Executive board composition and bank risk taking. Journal of Corporate Finance, 28, 48-65. doi: https://doi.org/10.1016/j.jcorpfin.2013.11.006

Bhimani, A., Gulamhussen, M. A., \& Lopes, S. D.-R. (2010). Accounting and non-accounting determinants of default: An analysis of privately-held firms. Journal of Accounting and Public Policy, 29(6), 517-532. doi: https://doi.org/10.1016/j.jaccpubpol.2010.09.009

Bikker, J., \& Metzemakers, P. A. (2004). Is bank capital procyclical? A cross-country analysis: In: De Nederlandsche Bank NV. Retrieved from: https://www.dnb.nl/media/1w3pv220/is_bank_capital-procyclical.pdf.

Bischof, J., \& Daske, H. (2012). Mandatory supervisory disclosure, voluntary disclosure, and risk-taking of financial institutions: Evidence from the EU-wide stresstesting exercises. 1-63. Retrieved from: https://abc-economie.banquefrance.fr/sites/default/files/media/2017/2003/2024/paper_bischof-daske.pdf.

Brucker, E. (1970). A microeconomic approach to banking competition. The Journal of Finance, 25(5), 1133-1141.

Brunnermeier, M. K., \& Yogo, M. (2009). A note on liquidity risk management. American Economic Revierw, 99(2), 578-583. 
Bryant, J. (1980). A model of reserves, bank runs, and deposit insurance. Journal of Banking \& Finance, 4(4), 335-344.

Campbell, J. Y., Hilscher, J., \& Szilagyi, J. (2008). In search of distress risk. The Journal of Finance, 63(6), $2899-2939$.

Cecchetti, Schoenholtz, S. G., \& Cecchetti, K. L. S. (2011). Money, banking, and financial markets (3rd ed.). New York: McGrawHill Education.

Chaibi, H., \& Ftiti, Z. (2015). Credit risk determinants: Evidence from a cross-country study. Research in International Business and Finance, 33, 1-16. doi: https://doi.org/10.1016/j.ribaf.2014.06.001

Chan, K., \& Chen, N. F. (1991). Structural and return characteristics of small and large firms. The Journal of Finance, 46(4), 14671484.

Chaplin, G., Emblow, A., \& Michael, I. (2000). Banking system liquidity: Developments and issues. Financial Stability Revierw, 4, 93-112.

Crowe, K. (2009). Liquidity risk management-more important than ever. Harland Financial Solutions, 3(1), 1-5.

Daily, C. M., \& Dalton, D. R. (1994). Corporate governance and the bankrupt firm: An empirical assessment. Strategic Management Journal, 15(8), 643-654. doi: https://doi.org/10.1002/smj.4250150806

Decker, P. A. (2000). The changing character of liquidity and liquidity risk mangement. Journal of Lending and Credit Risk Management, 82(8), 26-34.

Denis, D. J., Denis, D. K., \& Sarin, A. (1997). Agency problems, equity ownership, and corporate diversification. The Journal of Finance, 52(1), 135-160.

DeYoung, R., \& Jang, K. Y. (2016). Do banks actively manage their liquidity? Journal of Banking \& Finance, 66, 143-161. doi: https://doi.org/10.1016/j.jbankfin.2015.11.013

Diamond, D. W., \& Dybvig, P. H. (1983). Bank runs, deposit insurance, and liquidity. Journal of Political Economy, 91(3), 401-419.

Diamond, D. W., \& Rajan, R. G. (2001). Liquidity risk, liquidity creation, and financial fragility: A theory of banking. Journal of Political Economy, 109(2), 287-327.

Elloumi, F., \& Gueyie, J. P. (2001). financial distress and corporate governance: An empirical analysis. Corporate Governance, 1(1), 15-15.

Erkens, D. H., Hung, M., \& Matos, P. (2012). Corporate governance in the 2007-2008 financial crisis: Evidence from financial institutions worldwide. Journal of Corporate Finance, 18(2), 389-411.

Flagg, J. C., Giroux, G. A., \& Wiggins Jr, C. E. (1991). Predicting corporate bankruptcy using failing firms. Review of financial Economics, 1(1), 67-75.

Flannery, M. J. (2001). The faces of "market discipline. Journal of Financial Services Research, 20(2), 107-119.

Gombola, M. J., Haskins, M. E., Ketz, J. E., \& Williams, D. D. (1987). Cash flow in bankruptcy prediction. Financial Management, $16(4), 55-65$.

Hendel, I. (1996). Competition under financial distress. Journal of Industrial Economics, 44(3), 309-324. doi: https://doi.org/10.2307/2950499

Hirtle, B. (2007). Public disclosure, risk, and performance at bank holding companies. FRB of New York Staff Report, No. 293.

Ho, S. J., \& Hsu, S.-C. (2010). Leverage, performance and capital adequacy ratio in Taiwan's banking industry. Japan and the World Economy, 22(4), 264-272. doi: https://doi.org/10.1016/j.japwor.2010.06.007

Hossain, M. (2008). The extent of disclosure in annual reports of banking companies: The case of India.

Huang, G. (2006). The determinants of capital structure: Evidence from China. China Economic Review, 17(1), 14-36. doi: https://doi.org/10.1016/j.chieco.2005.02.007

Hussain, M. E., \& Hassan, M. K. (2005). Basel capital requirements and bank credit risk taking in developing countries.

IMF. (2014). Annual report (From Stabilization to Sustainable Growth) 700 19th street NW. Washington, DC 20431 USA: International Monetary Fund.

Jenkinson, N. (2008). Strengthening regimes for controlling liquidity risk: Some lessons from the recent turmoil. Bank of England. Quarterly Bulletin, 48(2), 223. 
Jokipii, T., \& Milne, A. (2008). The cyclical behaviour of European bank capital buffers. Journal of Banking E Finance, 32(8), 1440-1451. doi: https://doi.org/10.1016/j.jbankfin.2007.12.001

Konishi, M., \& Yasuda, Y. (2004). Factors affecting bank risk taking: Evidence from Japan. Journal of Banking Eं Finance, 28(1), 215-232. doi: https://doi.org/10.1016/s0378-4266(02)00405-3

Kwan, S., \& Eisenbeis, R. A. (1997). Bank risk, capitalization, and operating efficiency. Journal of Financial Services Research, 12(2), 117-131.

Laeven, L., \& Levine, R. (2009). Bank governance, regulation and risk taking. Journal of Financial Economics, 93(2), $259-275$.

Landskroner, Y., \& Paroush, J. (2008). Liquidity risk and competition in banking. NYU Working Paper No. FIN-07-053. Published. Retrieved from: https://archive.nyu.edu/bitstream/2451/26362/2/07-53.pdf.

Lee, C.-C., \& Hsieh, M.-F. (2013). The impact of bank capital on profitability and risk in Asian banking. Journal of International Money and Finance, 32, 251-281. doi: https://doi.org/10.1016/j.jimonfin.2012.04.013

Lee, T.-H., \& Chih, S.-H. (2013). Does financial regulation affect the profit efficiency and risk of banks? Evidence from China's commercial banks. The North American Journal of Economics and Finance, 26, 705-724. doi: https://doi.org/10.1016/j.najef.2013.05.005

Lin, S. L., Penm, J. H., Gong, S.-C., \& Chang, C.-S. (2005). Risk-based capital adequacy in assessing on insolvency-risk and financial performances in Taiwan's banking industry. Research in International Business and Finance, 19(1), 111-153. doi: https://doi.org/10.1016/j.ribaf.2004.10.006

Louzis, D. P., Vouldis, A. T., \& Metaxas, V. L. (2012). Macroeconomic and bank-specific determinants of non-performing loans in Greece: A comparative study of mortgage, business and consumer loan portfolios. Journal of Banking $\mathcal{E}^{\circ}$ Finance, 36(4), 1012-1027. doi: https://doi.org/10.1016/j.jbankfin.2011.10.012

Manzaneque, M., Priego, A. M., \& Merino, E. (2016). Corporate governance effect on financial distress likelihood: Evidence from Spain. Accounting Magazine, 19(1), 11 1-121. doi: https://doi.org/10.1016/j.rcsar.2015.04.001

Matz, L., \& Neu, P. (2006). Liquidity risk measurement and management: A practitioner's guide to global best practices (Vol. 408): John Wiley \& Sons.

Maudos, J., \& Nagore, A. (2005). Explaining market power differences in banking: A cross-country study: Valencian Institute of Economic Research. Retrieved from: http://web2011.ivie.es/downloads/2005/01/18/ponencia01.pdf.

Miglani, S., Ahmed, K., \& Henry, D. (2015). Voluntary corporate governance structure and financial distress: Evidence from Australia. Journal of Contemporary Accounting $\mathcal{E}^{2}$ Economics, 11(1), 18-30. doi: https://doi.org/10.1016/j.jcae.2014.12.005

Miller, D., \& Friesen, P. H. (1984). A longitudinal study of the corporate life cycle. Management Science, 30(10), 1161-1183. doi: https://doi.org/10.1287/mnsc.30.10.1161

Minton, B. A., \& Williamson, R. (2014). Financial expertise of the board, risk taking, and performance: Evidence from bank holding companies. Journal of Financial and Quantitative Analysis, 49(2), 351-380. doi: https://doi.org/10.1017/s0022 109014000283

Moulton, H. (1981). Commercial banking and capital formation. New York: St. In: Martins Press.

Nier, E., \& Baumann, U. (2006). Market discipline, disclosure and moral hazard in banking. Journal of Financial Intermediation, 15(3), 332-361. doi: https://doi.org/10.1016/j.jfi.2006.03.001

Ohlson, J. A. (1980). Financial ratios and the probabilistic prediction of bankruptcy. Journal of Accounting research, 18(1), 109-131. doi: https://doi.org/10.2307/2490395

Pasiouras, F., \& Kosmidou, K. (2007). Factors influencing the profitability of domestic and foreign commercial banks in the European Union. Research in International Business and Finance, 21(2), 222-237. doi: https://doi.org/10.1016/j.ribaf.2006.03.007

Putu, N., Moeljadi, D., \& Djazuli, A. (2014). Factors affecting firms value of Indonesia public manufacturing firms. International Journal of Business and Management Invention, 3(2), 35-44.

Rime, B. (2001). Capital requirements and bank behaviour: Empirical evidence for Switzerland. Journal of Banking \& Finance, 25(4), 789-805. doi: https://doi.org/10.1016/s0378-4266(00)00105-9 
Saunders, A., \& Corrnet, M. M. (2007). Financial institutions management: a risk management approach (M. Janicek Ed). 1221 Avenue of the Americas (6th ed.). New York, NY, 10020: The McGraw-Hill Companies, Inc.

Shaik, S. (2015). Impact of liquidity risk on variations in efficiency and productivity: A panel gamma simulated maximum likelihood estimation. European Journal of Operational Research, 245(2), 463-469. doi: https://doi.org/10.1016/j.ejor.2015.03.018

Shim, J. (2013). Bank capital buffer and portfolio risk: The influence of business cycle and revenue diversification. Journal of Banking Eீ Finance, 37(3), 761-772. doi: https://doi.org/10.1016/j.jbankfin.2012.10.002

Shin, H. S. (2009). Reflections on Northern Rock: The bank run that heralded the global financial crisis. Journal of Economic Perspectives, 23(1), 101-119. doi: https://doi.org/10.1257/jep.23.1.101

Stolz, S., \& Wedow, M. (2011). Banks' regulatory capital buffer and the business cycle: Evidence for Germany. Journal of Financial Stability, 7(2), 98-1 10. doi: https://doi.org/10.1016/j.jfs.2009.09.001

Tan, Y., \& Floros, C. (2013). Risk, capital and efficiency in Chinese banking. Journal of International Financial Markets, Institutions and Money, 26, 378-393. doi: https://doi.org/10.1016/j.intfin.2013.07.009

Theodossiou, P., Kahya, E., Saidi, R., \& Philippatos, G. (1996). Financial distress and corporate acquisitions: Further empirical evidence. Journal of Business Finance and Accounting, 23(5-6), 699-719. doi: https://doi.org/10.1111/j.14685957.1996.tb01149.x

Vazquez, F., \& Federico, P. (2015). Bank funding structures and risk: Evidence from the global financial crisis. Journal of Banking E Finance, 61, 1-14. doi: https://doi.org/10.1016/j.jbankfin.2015.08.023

Wooldridge, J. M. (2006). Introductory Econometrics: A Modern Approach. Thomson/South-Western, Mason, 3rd Edition.

Wruck, K. H. (1990). Financial distress, reorganization, and organizational efficiency. Journal of Financial Economics, 27(2), 419444. doi: https://doi.org/10.1016/0304-405x(90)90063-6

Zheng, H., \& Shen, Y. (2008). Jump liquidity risk and its impact on CVaR. The Journal of Risk Finance, 9(5), 477-491. doi: https://doi.org/10.1108/15265940810916139

Views and opinions expressed in this article are the views and opinions of the author(s), Asian Economic and Financial Review shall not be responsible or answerable for any loss, damage or liability etc. caused in relation to/arising out of the use of the content. 